\title{
Exílio, caminho de várias mãos (breve reflexão)
}

Franklin F. Morais ${ }^{1}$

\begin{abstract}
A pátria não é uma convenção territorial, é a imutabilidade da memória e do sangue. Não estar na Rússia, esquecer a Rússia - esse é o temor apenas de quem pensa a Rússia como exterior a si. Aquele que a tem dentro de si - só pode perdê-la quando perder a vida.
\end{abstract}

(Marina Tsvetáieva)

Somos ainda hoje uns desterrados em nossa terra.

(Sérgio Buarque)

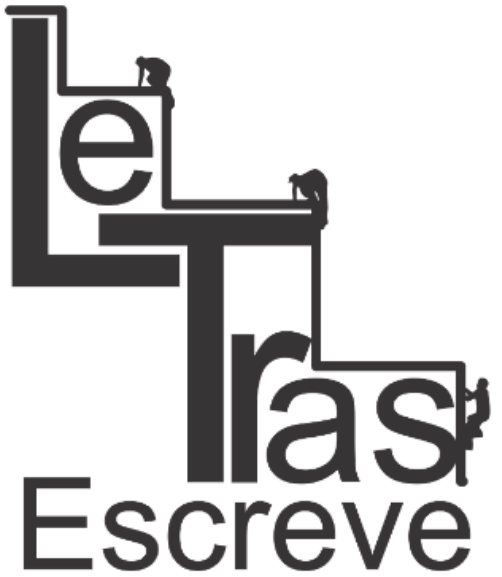

(ISSN 2238-8060)

Que os movimentos migratórios, espécie de mola de propulsão da experiência do exílio, deem ensejo a debates de temas variados - embates entre povos da Antiguidade; edificação de mitos sagrados em função de peregrinações; relatos de viagens exploratórias e científicas; imperialismo e diáspora coloniais; visões de identidade nacional em que se problematiza a influência imigratória; o autoexílio do intelectual de esquerda como contraponto radical à cultura de massa e à sociedade de consumo; a representação do exilado na prosa romanesca -, isso de certo modo projeta um campo de investigação de insólita unidade temática no qual perguntas de variada natureza podem ser formuladas.

Por exemplo, seria a experiência do exílio uma espécie de descolamento da paisagem natal, disjunção entre o eu e a nação que aos compatriotas protege pelo estatuto de cidadania? $\mathrm{O}$ que sugerem os registros memorialísticos provenientes desta experiência, talvez não tanto motivados por cataclismas naturais quanto pelo arbítrio político promovido pelo Estado: guerras civis, ditaduras fundamentalistas, fascistas, militares? Quais afetos são

${ }^{1}$ Doutorando em Teoria e História Literária pela Universidade Estadual de Campinas (UNICAMP).

https://periodicos.unifap.br/index.php/letras Macapá, v. 6, n. I, Io semestre, 2016. 


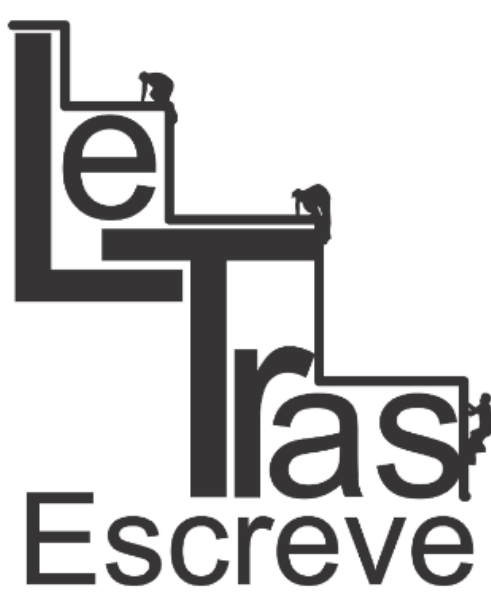

(ISSN 2238-8060) mobilizados nos discursos de exílio - a melancolia, o rancor, o ressentimento, o saudosismo envergonhado?

Há quem diga que quando o regime de cidadania é mutilado pela emergência do poder autoritário as frações mais robustas da resistência vê-se forçada $a$, como estratégia de sobrevivência política, buscar refúgio alhures. Surgem daí novas experiências de vida, no limite envoltas por paisagens estranhas, culturas exóticas e línguas desconhecidas em meio a quais não raro espantado está.

Sabe-se que a experiência dos regimes de exceção no século XX é atravessada por questões de imigração forçada: a literatura, o cinema, as artes plásticas, a ciência política produzidas então refletem em larga escala este problema. A luta geopolítica pelos territórios ultramarinos que desembocou nas duas guerras mundiais promoveu, como consequência, a diáspora em função do esbulho colonial e a redelimitação frequente das fronteiras nacionais europeias. A ideia de Era dos Extremos formulada por Eric Hobsbawn constitui-se, basicamente, como a época em que os limites fronteiriços não são apenas pretensão de poder político e econômico, mas defesa e estratégia bélicas de resguardo das instituições políticas, sustentáculos do Estado-nação. Os grandes eventos do século XX - entre os quais Revolução Russa de 1917, a expansão do bloco soviético e o colapso do Socialismo real, com a queda do muro de Berlim, e a integração ao capitalismo global; a decadência do Império Austro-Húngaro e do Império Otomano; a meteórica ascensão do Partido Nacional Socialista dos Trabalhadores Alemães e a loucura megalômana de Adolf Hitler para o confronto militar e a submissão de povos; o imperialismo norte-americano e o intervencionismo em países periféricos e Oriente Médio; e as ditaduras civis-militares da América Latina podem ser as placas tectônicas que, por assim dizer e a grosso modo, moviam como força de expuxo os limites nacionais, levandose às confrontações militares (na primeira metade do século) e aos duelos ideológicos "frios" e ao intervencionismo imperialista (na

https://periodicos.unifap.br/index.php/letras Macapá, v. 6, n. I, Io semestre, 2016. 


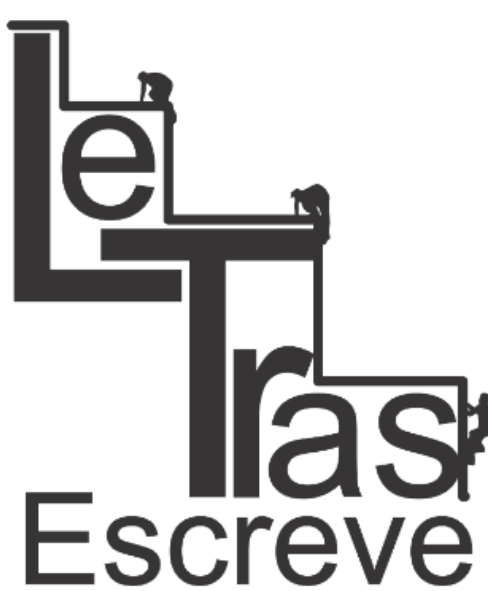

(ISSN 2238-8060) segunda metade) - além do pior dos eventos: os genocídios. A catástrofe das guerras e do autoritarismo político fez com que escritores, artistas, intelectuais, militantes políticos, guerrilheiros, pessoas dos mais diferentes estratos sociais e origens étnicas, buscassem refúgio em ares menos asfixiantes... Infelizmente não foi sempre o bastante.

Caso, por exemplo, da escritora russa Marina Tsvetáieva (1892-1941), que viveu nesta espécie de limbo apátrida por dezessete anos (1922-1939). Sua trágica, intensa e paupérrima vida no estrangeiro (Alemanha, Tchecoslováquia e França) está narrada em muitos de seus cadernos de diários e é tema constante da constante correspondência trocada com artistas, tradutores e intelectuais de diversos matizes ideológicos, constituindo-se como farto material para a análise da experiência da expatriação. Sua neutralidade ideológica a torna objeto da insolidariedade por parte da emigração soviética bolchevique que predominantemente comandava os aparelhos burocráticos das embaixadas da Europa Central. A reputação, digamos, ideológica de seu marido - Sergei Efron, ex-combatente do Exército Branco nos conflitos pela Crimeia na Guerra Civil Russa (1917-1921), ideólogo do movimento eurasiano e, a certa altura, agente NKVD, executado em 1941 num gulag, a quem Marina devota um companheirismo quase maternal, espécie de ligação irrompível -, decerto contribuiu para a reticência dos camaradas emigrados, sendo o que ela sugere em alguns escritos, ainda que timidamente, ciente do acirramento ideológico e das pressões políticas a que são submetidas ideias heterodoxas neste contexto. $2 \mathrm{~A}$ despeito do alto valor literário de seus poemas $\mathrm{e}$

\footnotetext{
${ }^{2}$ Escreve Marina em 28 de agosto de 1935: "Meu fracasso na emigração: sou uma não-emigrada, no espírito, isto é, pelo ar que respiro e pela envergadura - estou lá, venho de lá, vou para lá. Quanto ao meu conteúdo, devido à natureza homérica das dimensões, a emigração nada reconheceu. Aqui só tem sucesso o que é apagado - seria estranho esperar alguma coisa!". TSVETAIEVA, Marina. Vivendo sob o fogo: confissões. Seleção, organização e prefácio de Tzvetan Todorov; tradução do russo e do francês de Aurora Fornoni Bernardini. Martins Fontes: São Paulo, 2008, p. 419.
} 


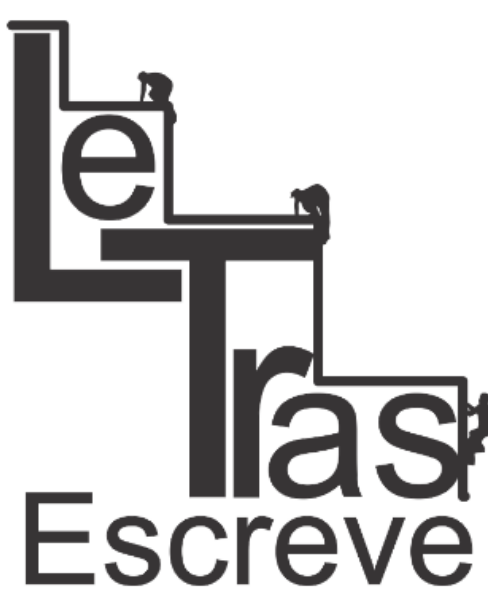

(ISSN 2238-8060) traduções, Marina viveu à míngua financeira e editorialmente, tendo o mínimo para a subsistência pela solidariedade de amigos mais próximos, sobretudo do poeta e romancista russo Boris Pasternak (1890-1960).

De modo semelhante e tendo o Brasil e a ditadura de Getúlio Vargas como agentes diretos de sua trajetória, como não lembrar da vida de Olga Benário (a quem Fernando Morais dedicou extensos esforços de pesquisa resultantes em livro), extraditada ilegalmente (já que grávida de pai cidadão brasileiro) do Rio de Janeiro para Hamburgo, vivendo seus últimos anos de vida em prisões da Gestapo e em campos de concentração nazistas, sendo vítima da "solução final"? Sua passagem pelo Brasil tivera como objeto uma revolução armada idealizada pelo comitê central do Partido Comunista soviético, que destina a Olga a missão no Brasil (ao lado de seu futuro marido e companheiro de Partido Comunista Luís Carlos Prestes, com quem muito se discutiu estratégia militar, um tema central em sua vida, sendo esse o nexo primeiro que aparentemente a liga a Prestes). A revolta armada fora completamente frustrada, não houve a adesão necessária das camadas militares que se ligavam à experiência revolucionária bolchevique, sendo a revolta frustrada sem muito derramamento de sangue. A partir daí o cerco vai sendo fechado ao grupo que planejara a revolta, e isso inclui a caçada a militantes políticos de várias nacionalidades instalados clandestinamente no Brasil (em especial no Rio de Janeiro). Ao lado de Prestes, Olga fora presa em 1936 pela polícia política de Getúlio Vargas - chefiada por Filinto Muller (1900-1973) - num pequeno aparelho improvisado no bairro do Méier. Sua vida se imbrica completamente à experiência do exílio e da clandestinidade, sendo talvez o capital cultural adquirido nessas peregrinações (poliglotismo e polivalência em linguagens políticas e artísticas) os vestígios mais interessantes de sua audaciosa e corajosa trajetória.

https://periodicos.unifap.br/index.php/letras Macapá, v. 6, n. I, Io semestre, 2016. 


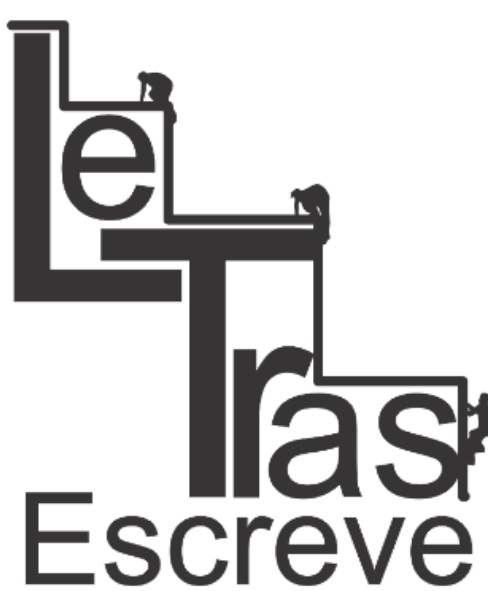

(ISSN 2238-8060)

Lado a lado, as vidas de Marina Tsvetáieva e Olga Benário uma cidadã russa que se exila na Europa Central, coração da civilização ocidental, mas que se suicida depois de uma tentativa de retorno à União Soviética, vítima da ortodoxia stalinista; e uma judia alemã que toma o país da revolução vermelha como pátria-mãe, e que morre, numa câmara de gás, sob o jugo do nazismo - revelam a confusão de direção dos, digamos, vetores das tensões ideológicas e conflitos geopolíticos da Era dos Extremos.

Esta embaraçosa (e, às vezes, inescapável) rede de ligações ideológicas e viagens de exílio é um tema fecundo cujo campo de exploração fora, no Brasil, pouco explorado. Exemplo disso é a série de livros de depoimentos e entrevistas com exilados brasileiros no período da Ditadura Militar (1964-1985) idealizada pela Editora e Livraria Livramento Ltda, dirigida e coordenada por Pedro Uchôa Cavalcanti e Jovelino Ramos, sob patrocínio de Paulo Freire, Abdias do Nascimento e Nelson Werneck Sodré. "A ideia nasceu de uma experiência de exílio. Brasileiros exilados na Polônia ficaram impressionados com o peso da memória coletiva na vida intelectual e política desse país", dizem os editores na explicação inicial da primeira e única edição que fora a prelo (Memórias do Exilio - Brasil 1964/19?? 1. de Muitos Caminhos), no prólogo em que expõem os critérios empregados da almejada empreitada editorial. Infelizmente, o projeto não passara do primeiro tomo, cuja corajosa publicação saíra ainda em 1976. Em alguma medida, o projeto que buscava remediar o caráter desmemoriado da cultura política no Brasil fizera menos que desejara, mas é a evidência cabal dos que buscaram peitar, no auge da repressão militar, o silêncio autoritariamente imposto, dando voz aos que deixaram o Brasil (não por necessariamente não amá-lo, como queria sugerir o slogan "Brasil, ame-o ou deixe-o" dos militares).

Encarnando este espírito e o atualizando frente a 2016, não poderia me furtar de, agora e por fim, dizer: fora, Temer! 


\section{Referências bibliográficas}

CAVALCANTI, Pedro Uchôa; RAMOS, Jovelino (org). Memórias do Exilio - Brasil de Muitos Caminhos. Editora e Livraria Livramento Ltda: São Paulo, 1976.

HOBSBAWN, Eric. A era dos extremos: o breve século XX (19141991). Companhia das Letras: São Paulo, 1998.

- A era dos impérios (1875-1914). Paz e Terra: Rio de Janeiro, 2001.

MORAIS, Fernando. Olga: A vida de Olga Benario Prestes, judia comunista entregue a Hitler. Editora Alfa-ômega: São Paulo, 1976.

TSVETAIEVA, Marina. Vivendo sob o fogo: confissões. Seleção, organização e prefácio de Tzvetan Todorov; tradução do russo e do francês de Aurora Fornoni Bernardini. Martins Fontes: São Paulo, 2008. . Indícios flutuantes (poemas). Tradução de Aurora Fornoni Bernardini Martins Fontes. Martins Fontes: São Paulo, 2006.

Recebido em 04/o8/2016. Aprovado em 27/08/2016. 